\title{
Measuring Motivations for Choosing Ecolabeled Seafood: Environmental Concerns and Warm Glow a $₫$
}

\author{
Julia Bronnmann Assistant Professor, Department of Sociology, Environmental and Business Economics, \\ University of Southern Denmark, Esbjerg; jubr@sam.sdu.dk \\ Max Thilo Stoeven Alumnus, Department of Economics, Kiel University, Germany; Stoeven@posteo.de \\ Martin Quaas Professor, German Centre for Integrative Biodiversity and Department of Economics, \\ Leipzig University, Germany; martin.quaas@idiv.de \\ Frank Asche Professor, School of Forest, Fisheries and Geomatics Sciences and the Food Systems \\ Institute, University of Florida, Gainesville; Department of Industrial Economics, University of \\ Stavanger, Norway; frank.asche@ufl.edu
}

\begin{abstract}
Ecolabels are supposed to reduce the information asymmetry between producers and consumers, but they may also produce a warm glow of "green" behavior. We design discrete choice experiments to measure the relative importance of these motivations for choosing ecolabeled seafood products. We find that choice probability increases if the product carries an ecolabel, but the magnitude of this effect depends on the information provided about the sustainability of the product. Overall, we attribute $63 \%$ of the ecolabel's original effect on choice probability to consumer demand for sustainable products, and a further $24 \%$ to warm glow. (JEL C25, Q21)
\end{abstract}

\section{Introduction}

Consumers have become increasingly sensitive to environmental issues related to food production in the past decades (Onozaka and McFadden 2011). Major retail chains have responded by increasing their efforts to supply sustainably sourced and ecolabeled products. ${ }^{1}$

\footnotetext{
${ }^{1}$ In Europe and North America, some retailers have committed themselves to excluding uncertified seafood from their assortment, such as Tesco, Sainsbury's, Wal-Mart, Whole Foods, Metro, Lidl, and Spar. Some of them committed to only selling Marine Stewardship Council (MSC)-certified seafood. For example, an association of Dutch retailers agreed that by 2011 all wild-caught seafood at every retailer

Land Economics • August 2021 • 97 (3): 641-654 ISSN 0023-7639; E-ISSN 1543-8325 (C) 2021 by the Board of Regents of the University of Wisconsin System
}

To foster credibility, ecolabels are often provided by third parties separate from the industries that produce and sell the ecolabeled product. Well-known ecolabels include the organic label for agricultural products established by the U.S. Department of Agriculture (USDA), the organic label for agricultural products in the European Union, the German Blue Angel, and the Forest Stewardship Council (FSC) label for timber. In the seafood market, the focus of this study, prominent labels include the Marine Stewardship Council (MSC), the Aquaculture Stewardship Council (ASC), Best Aquaculture Practice, and Friend of the Sea. ${ }^{2}$ A number of studies have found price premiums for ecolabeled seafood products mostly in the range of 10\%-15\% (Sogn-Grundvåg, Larsen, and Young 2013; Asche et al. 2015) but are heterogeneous across products, markets, and supply chains (Bronnmann and Asche 2016; Asche and Bronnmann 2017). This suggests that the market value of ecolabels in seafood may be imore than a US\$100 million. ${ }^{3}$ Moreover, ecolabels influence product substitution (Roheim and Zhang 2018) and shelf life (Sogn-Grundvåg et al. 2019).

\footnotetext{
in the Netherlands should be MSC-certified (Marx, Maertens, and Swinnen 2012). Lidl Germany and Lidl UK only sell MSC-labeled wild fish from 2017 onward, and from 2018 all farmed fish in the assortment will be certified by Aquaculture Stewardship Council (ASC) or organic (Lidl 2018).

${ }^{2}$ Currently, there exist 463 ecolabels in 199 countries and 25 industry sectors (Ecolabel Index 2018).

${ }^{3}$ The MSC annual report for $2018 / 2019$ notes that in the reporting period, $15 \%$ of the global marine fish catch was MSC-certified, and MSC-labeled seafood products had market value of US\$9.1 billion.
} 
Despite the important and growing market for ecolabels, it is unclear what consumers expect from them and what their motivation is for buying ecolabeled products (Thøgersen, Haugaard, and Olesen 2010; Grunert, Hieke, and Wills 2014), especially in the seafood market (Brécard et al. 2009). Ecolabels are supposed to provide easily accessible information about the environmental and sustainability attributes of a good's production process that consumers cannot infer from the product and cannot easily observe themselves (Leire and Thidell 2005). By providing credible information about the sustainability of the production process, ecolabels transform credence attributes into search attributes (Sammer and Wüstenhagen 2006), and thus they help consumers identify public good provision in production processes (Mason 2006). Hence, when buying ecolabeled products rather than nonlabeled ones, consumers may do so because of the information about public good provision in the production of otherwise indistinguishable products.

A recent body of literature, partly outside economics, has put forward an alternative explanation for why consumers may purchase more expensive products carrying an ecolabel (Hartmann et al. 2017; van der Linden 2018). These studies propose a "warm glow" effect (Andreoni 1989, 1990) associated with "green behavior," that is, the good feeling of doing good. ${ }^{4}$ The empirical observation that people donate to charities even if their donations are crowded out dollar-by-dollar (Crumpler and Grossman 2008) is explained by a private benefit from warm glow that is independent of the underlying public good. This article aims to empirically disentangle these effects as in the theoretical analysis of Grolleau, Ibanez, and Mzoughi (2009) and measure the relative importance of the environmental concerns and the warm glow motivations for choosing an ecolabeled product. This differentiation is policy relevant. To the extent that ecolabels help consumers contribute to environmental public good provision, they deserve public support. A warm glow effect, by contrast, does not jus-

\footnotetext{
${ }^{4}$ This effect may be even stronger if one shows other people that one does good, what Sexton and Sexton (2014) label the environmental halo effect.
}

tify any public intervention in the market, as it is a purely private good.

To quantify the relative importance of the two effects, we use data from three discrete choice experiments with a representative sample of German seafood consumers, where treatment groups receive different information regarding the MSC ecolabel. Without any prior framing, seafood-consuming participants were randomly allocated to one of three independent experiments in which they chose between three alternatives: two physically indistinguishable fish products and a no-choice alternative. In the first experiment, the fish products differ only in the attributes of price and whether they carry an ecolabel. This experiment allows assessing the participants' preferences for ecolabeled products and is similar to previous studies on stated preference or willingness to pay for ecolabels. This experiment in isolation does not allow disentangling different motivations for buying an ecolabeled product. The two additional experiments are designed to isolate and quantify the effects that an ecolabel may serve as an information device to choose a sustainable product (environmental concerns motivation) or that it allows the consumer to enjoy a certified "good" choice (warm glow motivation). In the second and third experiments, additional product attributes with respect to the sustainability of the product, namely, fish stock status, catch area, and bycatch intensity, are included and enable the consumers to directly identify environmentally friendly products. Given that these attributes capture the most important aspects of seafood sustainability, the extra information should make redundant the function of the ecolabel to provide information about environmental public good provision. A remaining preference for the MSC label is accordingly associated with a warm glow.

To test the interpretation that the participants processed the information about the public good (stock status, bycatch intensity) and still cared for the ecolabel because of warm glow, the second and third experiments were designed to provide different indications about the "greenness" of the ecolabeled product. In the second experiment, the information about stock status and bycatch intensity 
was consistent with the information provided by the presence of the ecolabel. An ecolabel was only present for fish products with a "not overfished" stock status and "low bycatch." In the third experiment, participants faced alternatives where an ecolabeled product was declared to come from a stock classified as "overfished" or from a "high bycatch" fishery. This is in line with the empirical literature showing evidence for unsustainable production processes even in certified fisheries (Gutiérrez et al. 2012; Martin et al. 2012; Christian et al. 2013; Opitz et al. 2016) and forestry (Blackman, Goff, and Rivera Planter 2018).

Our results indicate that a major motivation for choosing ecolabeled seafood is the contribution to the environmental public good provision. This finding is policy relevant, as this should deserve public support. However, we also find that people who buy the ecolabeled product experience a warm glow benefit. Because this is a purely private benefit, it does not provide reason for public intervention. Overall, we attribute $63 \%$ of the ecolabel's original effect on choice probability to consumer demand for sustainable products and $24 \%$ to warm glow.

\section{Experimental Design and Data}

Our stated choice experiment on consumers' preferences for purchasing ecolabeled marine fish products was embedded in an online questionnaire and conducted in Germany in two weeks in November 2017. The survey only addressed consumers who reported that they eat fish in a screening question. The main part of the survey consisted of three independent discrete choice experiments (DCEs). This approach builds on a large literature that analyzes seafood ecolabels using DCEs (Wessell, Johnson, and Donath 1999; Johnston et al. 2001; Jaffry et al. 2004; Johnston and Roheim, 2006; Brécard et al. 2009; Salladarré et al., 2010; Uchida et al., 2014a, 2014b; Fonner and Sylvia 2015; Bronnmann and Asche 2017; Bronnmann and Hoffmann 2018). After the introductory question to identify seafood consumers, each participant was randomly allocated to one of the three experiments. To avoid any framing effects, the choice exper- iments started directly after a short explanatory text. In the DCEs, participants were asked to make repeated choices between two fish products and a no-choice alternative. In all choice experiments, the physical product was a frozen $250 \mathrm{~g}$ package of cod fillets, a common product in German retailing. After the choice experiments, the participants were asked several questions about their fish consumption behavior.

Focus group discussions with 10 participants helped inform development of the questionnaire. In particular, the attributes were chosen, and the identification strategy was determined, based on the outcomes of the focus group discussion. The focus group was used to identify the criteria and topics that participants felt were important for the sustainability component of seafood. To ensure the comprehensibility of the choice sets and the questions, the survey was pretested online. 5

For the final survey, a total sample of 2,924 people were invited via a privately managed online panel of the marketing agency Trend Research, which is located in Hamburg, Germany. The agency recruited the respondents online from their panel and invited them by email to answer our survey questions. The panelists who did not reply initially were reminded once with a follow-up email. Participation was incentivized by the marketing agency. The respondents received reward points "Trendies," which can be exchanged at the premium shop Trendfrage.de for various premiums. In addition, people who completely filled out the survey and supplied their email address took part in a prize draw to win $€ 500$.

A total of 265 respondents dropped out through the screening question, as they were not consuming fish at all. From the 2,659 $(91 \%)$ remaining respondents, $1,453(55 \%)$ filled out the questionnaire completely and were included in the analysis.

The first DCE included two attributes, price and ecolabel. To be specific, the MSC ecolabel, which is the most widespread and well-known ecolabel for seafood in Germany,

\footnotetext{
${ }^{5}$ The participants for the pretest were recruited through mailing lists. A total of 789 participants completed the pretest, yielding a completion rate of $86 \%$.
} 
Table 1

\begin{tabular}{lll}
\multicolumn{3}{c}{ Attributes and Attribute Level } \\
\hline \multirow{3}{*}{ Attribute } & $\begin{array}{c}\text { Experiment } 1 \\
\text { Attribute Level }\end{array}$ & $\begin{array}{l}\text { Experiments } 2 \text { and } 3 \\
\text { Attribute Level }\end{array}$ \\
\hline Price & $€ 1.92 / 250 \mathrm{~g}$ & $€ 1.92 / 250 \mathrm{~g}$ \\
& $€ 3.36 / 250 \mathrm{~g}$ & $€ 3.36 / 250 \mathrm{~g}$ \\
& $€ 4.40 / 250 \mathrm{~g}$ & $€ 4.40 / 250 \mathrm{~g}$ \\
& $€ 8.03 / 250 \mathrm{~g}$ & $€ 8.03 / 250 \mathrm{~g}$ \\
MSC label & Yes & Yes \\
& No & No \\
Catch area & & Marine fisheries worldwide \\
& & European marine fisheries \\
& & North Sea or Baltic Sea \\
Stock status & & Heavily overfished \\
& & Slightly overfished \\
Bycatch of birds or marine mammals & & Not overfished \\
& & Low \\
\hline
\end{tabular}

was chosen. In the second and third DCEs, the frozen cod fillets varied in price, ecolabel, catch area, stock status, and bycatch. The attributes and their related levels are summarized in Table 1.

Price levels were calculated based on a sample of 2,419 German supermarket price observations using scanner data from the Gesellschaft für Konsumforschung of cod products purchased in German supermarkets in 2016. Four price levels were used: the mean market price $(€ 3.36 / 250 \mathrm{~g})$, the mean minus one standard deviation, and the mean plus one and the mean plus two standard deviations. Each level of the different attributes is shown a similar numbers of times in the choice experiment, for not giving disproportional weight to single attributes (Wittink, Krishnamurthi, and Nutter 1982).

Earlier studies and the pretest showed that consumers are not able to locate the official catch area names, based on United Nations Food and Agriculture Organization (FAO) standards, that are mandatory on packaging in the European Union. For this reason, the German coastal seas (the North Sea and the Baltic Sea) were used as the attribute level for regional products. The attribute levels with the terms "European" and "worldwide" are increasingly more broadly defined fishing areas. This specification allows us to measure the extent to which consumers care for the regionality of the products. Stock status was described by variants of the commonly known term "overfished," as these notions were more clearly understood by the German consumers than the official FAO terms "underfished" and "fully fished." Because the amount of bycatch is highly area- and gear-specific and consumer knowledge about these specificities is probably limited, the formulations "low bycatch/ high bycatch" were used to indicate the degree of bycatch.

The second and third DCEs differed with respect to the attribute level combinations of the attributes "MSC label," "Stock status", and "Bycatch" presented to the participants. In experiment 3, no restrictions on attribute level combinations were used. As a consequence, participants were confronted with combinations such as stock status "heavily overfished" and MSC label "yes." In the second experiment, these seemingly contradictory attribute level combinations were excluded. Thus, the three experiments differed in the number of attributes (experiment 1 vs. experiments $2+$ 3 ) and in the control for contradictions (experiment 2 vs. experiment 3 ).

To build the sets of choice cards for each of the experiments, multinomial logit models (MNLs) were estimated using the pretest data. The estimates were used as priors in the software Ngene to generate 24 choice cards for the three DCEs to maximize the D-efficiency measure for the panel mixed MNLs (panel MMNLs). The Ngene code is available in the Appendix. In the pretest we used three blocks of choice cards, resulting in 10 choice cards 
Table 2

Exemplary Choice Card of Treatment 3

\begin{tabular}{llll}
\hline & Product 1 & Product 2 & \\
\hline Price in $€$ per $250 \mathrm{~g}$ & 8.03 & 3.36 \\
Catch area & Fisheries worldwide & North Sea or Baltic Sea & Neither of these products \\
Stock status & Heavily overfished & Not overfished & \\
Bycatch & High & Low & \\
MSC label & Yes & No & 0 \\
I choose: & 0 & 0 &
\end{tabular}

Table 3

Descriptive Statistics for the Participants

\begin{tabular}{llcccc}
\hline Variable & Description & T 1 & T 2 & T 3 & Microcensus \\
\hline Age & Median age & 50 & 49 & 49 & 50 \\
Male & Percentage share of male participants & 50 & 50 & 52 & 65 \\
HH size & Average number of people living in the household & 2.30 & 2.40 & 2.30 & 2.30 \\
Kids & Average number of kids living in the household & 0.30 & 0.40 & 0.40 & 0.40 \\
Monthly net income & Median monthly net income (€) & 2,250 & 2,250 & 2,750 & 3,064 \\
Married & Percentage share of married participants & 48 & 50 & 48 & 58 \\
Full-time job & Percentage share of participants employed full-time & 52 & 54 & 57 & 64 \\
Participants & & 438 & 511 & 505 & 11,570 \\
\hline
\end{tabular}

aThe income is defined as income per participant in the survey, and in the microcensus it is the household income.

per participant. Due to a configuration error, the entire set of 24 choice cards was shown in random order to individuals in the main experiment. However, as the estimation results of the actual experiments with 24 choice cards per participant were consistent to our pretest results with 10 choice cards per participant, choice fatigue does not seem to be a problem. Louviere (2004) argued that it is important not to have too few choice sets in a design, as ceteris paribus more information about preferences of the participants are obtained with more choice sets. Furthermore, Louviere $(2004,18)$ wrote that it is an "academic urban myth" that individuals can just handle small designs, and there is considerable evidence that participants can do a lot of choice sets. For instance, Hensher, Stopher, and Louviere (2001) investigated the effects of different numbers of choice sets $(4,8,12$, 24 , and 32) on response variability and model parameters in designed choice experiments and found only minor differences in estimated elasticities. Carlsson and Martinsson (2008) also tested choice designs with 12 and 24 choice sets and found that neither the number of choice sets nor the design of the first choice set has a significant effect on estimated marginal willingness to pay.

An exemplary choice card for the third experiment is shown in Table 2.

\section{Data Description}

A total of 1,453 survey responses were collected: 437 in treatment 1,511 in treatment 2, and 505 in treatment 3; all were included in the analysis. The respondents' sociodemographic characteristics are similar between the three treatments, as shown in Table 3, along with the average household data from the microcensus (2008) collected by the German Federal Statistical Office (Destatis 2008). For key demographic variables, the data correspond closely with the data from the German microcensus. Hence, we conclude that the data used for the analyses are representative of the German population.

The respondents' sociodemographic characteristics were similar between the three treatments. ${ }^{6}$ The whole sample covered the main education and employment groups. A re-

\footnotetext{
${ }^{6}$ Appendix Table A1 shows the sociodemographic variables for each treatment separately.
} 
Figure 1

Types of Information Used When Buying Fish

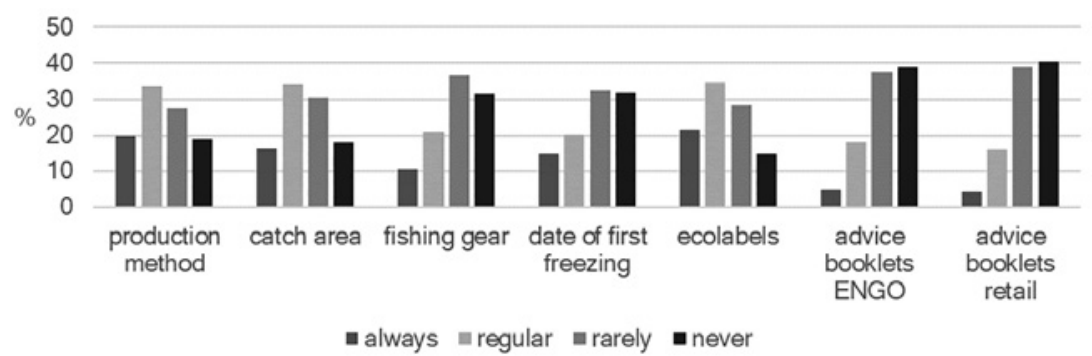

spondent was most likely male, 49 years old, married, had at least a secondary school certificate, and was in full- or part-time employment with a monthly per capita net income between $€ 2,000$ and $€ 2,499.7$ The median respondent lived in a two-person household with 0.3 children and was the responsible person for shopping for everyday commodities in the household. Most of the respondents ate fish once or twice a week (38.5\%).

The respondents bought their fish at different types of retailers. The most often named type were supermarket (46\%), followed by discounter (24\%), fishmonger (13\%), farmers' market (8\%), others (4\%), and fishermen $(4 \%)$. The least often named option was to buy fish online (1\%).

When asked, "How often do you use the following types of information when buying seafood?," the majority (56\%) of the respondents stated that they always or regularly look for ecolabels when buying seafood. In addition, the production method $(53 \%)$ and the catch area $(51 \%)$ are information the respondents always or regularly look for to inform their buying decisions. In contrast, information regarding the fishing gear, date of first freezing, or advice booklets from environmental nongovernmental organizations (ENGOs) and retailers are in most cases rarely or never used when buying seafood.

Two thirds of the respondents were aware of the MSC ecolabel. Moreover, $49 \%$ of the respondents agree with the statement that their buying behavior can help protect waters

\footnotetext{
${ }^{7}$ For the analyses, the respondents net income was defined as low, when it is $<=€ 750$ and was defined as high when it exceeds $€ 2,750$.
}

from overfishing. Figure 1 depicts which information the participants use to assess the environmental impact related their seafood buying decision.

Consumers assess the production method, the catch area, and whether the product carries an ecolabel to be important product characteristics. The type of fishing gear, the date of first freezing, and information contained in shopping guides from retailers or ENGOs were far less important for the buying decision.

\section{Model Specifications}

The discrete choice model is based on random utility theory (McFadden 1974) and assumes that respondents choose the fish product or the opt-out alternative that provides the highest level of utility. We model utility as depending on the price of the product, the presence of the MSC label, catch area, degree of overfishing, and degree of bycatch. Mixed logit models with random parameters across decision-makers show the relevant advantage of allowing for taste heterogeneity unconditional on socioeconomic covariates (Grebitus, Jensen, and Roosen 2013). Moreover, the approach solves all restrictions of standard logit models: this model relaxes the independence of irrelevant alternatives (IIA) assumption and, allows for random taste variation and the correlation of unobserved factors over time. The main goal for the coefficients that have been selected to vary randomly is to estimate the moments of the distribution (e.g., the mean and the variance of the normal distribution) instead of only estimating a point estimate. 
Because each respondent in our survey is repeatedly observed, a panel MMNL is applied to analyze the experiments. In choice situation $t$, the respondent $n$ has to choose one of the two fish products $i=1,2$ or the opt-out alternative. Although the utility level of the opt-out alternative is normalized to zero, the utility level of the cod fillet alternative $i$ in model 1 is

$U_{n i t}=\beta_{0}$ Constant $+\beta_{1}$ Price

$+\left(\beta_{2}+\sigma_{2} u_{n 2}\right)$ MSC Label: Yes $+\varepsilon_{n i t}$.

$\beta_{0}$ Constant is the alternative specific constant capturing the average effect of all unobserved factors associated with purchasing cod on utility. The alternative specific constant is the "to buy" or "choice" option. We included only one constant in the model, because we use an unlabeled choice experiment and the product alternatives are described by their attributes. The constant $\beta_{0}$ takes the value zero if the respondent opts out and one if the respondents choose one of the products. For the price we use the actual level for each of the four specifications. The dummy variable MSC label: Yes indicates the presence of the MSC label in the choice card.

In models 2 and 3, the utility function was adjusted as follows to include the additional attribute levels:

$$
\begin{aligned}
U_{n i t}= & \beta_{0}+\beta_{1} \text { Price } \\
& +\left(\beta_{2}+\sigma_{2} u_{n 2}\right) \text { MSC - Label } \\
& +\left(\beta_{3}+\sigma_{3} u_{n 3}\right) \text { Fisheriesworldwide } \\
& +\left(\beta_{4}+\sigma_{4} u_{n 4}\right) \text { Europeanfisheries } \\
& +\left(\beta_{5}+\sigma_{5} u_{n 5}\right) \text { Heavilyoverfished } \\
& +\left(\beta_{6}+\sigma_{6} u_{n 6}\right) \text { Slightlyoverfished } \\
& +\left(\beta_{7}+\sigma_{7} u_{n 7}\right) \text { Bycatch }: \text { High }+\varepsilon_{n i t},
\end{aligned}
$$

where $u_{n 2}, \ldots, u_{n 7}$ are independently and identically distributed (iid) standard normal, reflecting the assumption that preference heterogeneity exists across but not within respondents. The unobserved part of utility, $\varepsilon_{\text {nit }}$, is assumed to be iid extreme value type 1 .

This specification treats the effect of the constant and the price variable as fixed across participants, whereas the coefficients for all other variables vary randomly across participants. Setting all dummy variables to zero generates the baseline attribute level combination "North Sea or Baltic Sea I Not overfished I Bycatch: Low I MSC label: No" in models 2 and 3.

\section{Empirical Results}

For the three DCEs, a panel MMNL model is estimated. All models were estimated with and without sociodemographic variables. The socioeconomic characteristics are included as interaction terms with the alternative specific constant to capture the effect on the likelihood of adoption. Comparing the results with the main effect models, we find that the results are very robust. We decided to present the models with sociodemographic variables, as it gives further information. The sociodemographic variables were selected based on previous literature (Zhou, Hu, and Huang 2016; Bronnmann and Asche, 2017; Bronnmann and Hoffmann, 2018;).

Tables 4-6 report the estimated results and marginal effects. The marginal effects capture how the likelihood of choice changes at the margin with the respective independent variable. For discrete variables, it is not appropriate to calculate the marginal effect in terms of infinitesimal changes. Based on the approach of Hole (2007), the marginal effects were thus calculated at the sample mean, and subsequently a discrete change (from zero to one) of the variable of interest was simulated that leads to a change in the corresponding choice probability. The difference of both probabilities represents the average marginal effect of the dummy variable.

As expected, and in accordance with economic theory, the price coefficient was negative and statistically different from zero in all DCEs. Furthermore, the standard deviations of the random coefficients are significant in most cases, indicating heterogeneous consumer preferences. This confirms that it is appropriate to use the panel MMNL.

Table 4 shows the results for model 1 . The marginal effect shows that the presence of the MSC label raises the choice probability of a fish product by 25 percentage points on average. The socioeconomic covariates show that male respondents are more likely to buy cod 
Table 4

Estimation Results of the Panel MMNL, Model 1

\begin{tabular}{|c|c|c|c|c|c|}
\hline & Coefficient & Std. Err. & $\begin{array}{c}\text { Marginal } \\
\text { Effect Mean }\end{array}$ & ME Max & ME Min \\
\hline \multicolumn{6}{|l|}{ Mean } \\
\hline Constant & $3.031 * * *$ & 0.35 & & & \\
\hline Price & $-0.929 * * *$ & 0.03 & -0.106 & -0.219 & -0.021 \\
\hline Age & $-0.009 * *$ & 0.04 & -0.001 & -0.002 & -0.001 \\
\hline Male & $0.667 * * *$ & 0.11 & 0.069 & 0.001 & 0.164 \\
\hline $\mathrm{HH}$ size & 0.117 & 0.07 & 0.012 & 0.001 & 0.029 \\
\hline Kids & $-0.460 * * *$ & 0.16 & -0.045 & -0.114 & -0.001 \\
\hline Low income & -0.308 & 0.202 & -0.031 & -0.077 & -0.001 \\
\hline High income & $-0.421 * * *$ & 0.123 & -0.041 & -0.105 & -0.001 \\
\hline Employed & -0.180 & 0.112 & -0.018 & -0.045 & -0.001 \\
\hline Single & -0.207 & 0.135 & -0.020 & -0.051 & -0.001 \\
\hline MSC label & $2.342 * * *$ & 0.15 & 0.252 & 0.019 & 0.471 \\
\hline \multicolumn{6}{|l|}{ SD Standard Deviation } \\
\hline MSC label & $2.041 * * *$ & 0.13 & & & \\
\hline Aike Information Criterium & $4,494.10$ & & & & \\
\hline Log-likelihood & $-2,235.05$ & & & & \\
\hline Observations & 7,866 & & & & \\
\hline Participants & 437 & & & & \\
\hline
\end{tabular}

products. A higher age, more children in the household, or a high income reduces the purchase probability of frozen cod fillet. A possible explanation is that those households prefer to buy fresh fish.

Treatment 2 included the additional product attributes catch area, stock status, and bycatch intensity. Table 5 shows the estimated coefficients for model 2. All the additional variables are statistically significant and reduce the probability of purchasing the product. Hence, the respondents were less likely to select cod products that originated from overfished stocks, and more so for severely overfished stocks, as well as from fisheries with a high bycatch. These results show that the respondents strongly care about overfishing and bycatch issues when purchasing seafood.

The MSC label is still statistically significant. The marginal effect of the MSC label shows that its presence still raises the purchase probability by around 9 percentage points. Compared to model 1 , however, this is a reduction of about $63 \%$. Having lost its function to provide information on seafood sustainability, the coefficient of the MSC label now only captures a motivation of preferring the MSC-certified product beyond the provision of information, which is interpreted as consumers enjoying the warm glow of buying the ecolabel. The significantly positive parameter estimate indicates that such a warm glow effect exists.

To test the information-providing value of the MSC label for consumers, the third-choice experiment included contradictory attribute-level combinations ("Heavily overfished and MSC label: Yes" or "high bycatch and MSC label: Yes"), so that the MSC label does not necessarily provide trustworthy information that the certified product comes from a sustainably fished source. This should remove their feeling of doing good when selecting an MSC-certified product and thus also take away the warm glow effect. The results are displayed in Table 6.

As in the second DCE, the respondents have a lower probability of purchasing fish products from fisheries that are overfished or that are characterized by high bycatches. Introducing contradictory product attributes in model 3, two important differences are found compared to model 2 . First, the negative coefficients for catch areas become significant, in- 
Table 5

Estimation Results of the Panel MMNL, Model 2

\begin{tabular}{|c|c|c|c|c|c|}
\hline & Coefficient & Std. Err. & $\begin{array}{c}\text { Marginal } \\
\text { Effect Mean }\end{array}$ & ME Min & ME Max \\
\hline \multicolumn{6}{|l|}{ Mean } \\
\hline Constant & $3.689 * * *$ & 0.24 & & & \\
\hline Price & $-0.326^{* * *}$ & 0.01 & -0.039 & -0.078 & -0.008 \\
\hline Age & $-0.026 * * *$ & 0.01 & -0.003 & -0.006 & -0.001 \\
\hline Male & $0.305^{* * *}$ & 0.06 & 0.033 & 0.001 & 0.071 \\
\hline HH size & -0.013 & 0.45 & -0.001 & -0.003 & -0.001 \\
\hline Kids & 0.063 & 0.10 & 0.007 & 0.001 & 0.015 \\
\hline Low income & $-0.443 * * *$ & 0.13 & -0.046 & -0.105 & -0.001 \\
\hline High income & $-0.185^{* * *}$ & 0.07 & -0.019 & -0.044 & -0.001 \\
\hline Employed & $-0.286^{* * *}$ & 0.08 & -0.030 & -0.069 & -0.001 \\
\hline Single & $-0.210 * *$ & 0.08 & -0.022 & -0.051 & -0.001 \\
\hline Fisheries worldwide & -0.071 & 0.05 & -0.007 & -0.034 & 0.010 \\
\hline Fisheries EU & -0.033 & 0.05 & -0.003 & -0.025 & 0.013 \\
\hline Heavily overfished & $-2.950 * * *$ & 0.11 & -0.241 & -0.537 & -0.001 \\
\hline Slightly overfished & $-0.805^{* * *}$ & 0.07 & -0.066 & -0.210 & 0.026 \\
\hline Bycatch & $-2.009 * * *$ & 0.09 & -0.154 & -0.436 & 0.046 \\
\hline MSC label & $1.026^{* * *}$ & 0.08 & 0.094 & -0.049 & 0.285 \\
\hline \multicolumn{6}{|l|}{ Standard Deviation } \\
\hline Fisheries worldwide & $0.507 * * *$ & 0.08 & & & \\
\hline Fisheries EU & $0.423 * * *$ & 0.08 & & & \\
\hline Heavily overfished & $2.028 * * *$ & 0.09 & & & \\
\hline Slightly overfished & $1.673 * * *$ & 0.08 & & & \\
\hline Bycatch & $2.717 * * *$ & 0.11 & & & \\
\hline MSC label & $2.057 * * *$ & 0.09 & & & \\
\hline Aike information criteria & $18,124.45$ & & & & \\
\hline Log-likelihood & $-9,040.23$ & & & & \\
\hline$N$ & 36,792 & & & & \\
\hline Participants & 511 & & & & \\
\hline
\end{tabular}

dicating that respondents start to prefer local fish products over more distant product origins when attribute-level contradictions impair the credibility of the MSC label. This finding is in line with Onozaka and McFadden (2011), who find that certification mitigates the negative valuation of imported products. Second, the effect of the MSC label on purchase probability is further reduced. Interpreting this decrease of the MSC's marginal effect between models 2 and 3 as the size of the warm glow, the marginal effect of the ecolabel observed in the first experiment $(0.252$ [100\%]) can be disentangled into its information about environmental concerns function (0.158 [63\%]), its warm glow function $(0.060$ [24\%]), and a residual marginal effect $(0.034$ [13\%]). This residual marginal effect can be attributed to participants who are highly committed to the idea that ecolabels help for achieving sustainability. When presented product information that contradicts the image of the MSC label, high-commitment consumers may discount such negative information more than their low-commitment counterparts (Ahluwalia, Burnkrant, and Unnava 2000). This can be linked to theories on belief harmonization (Dunning 2007), according to which consumers try to maintain the established link between the MSC-certified product and their motives.

Consumer characteristics influence the choice probability of buying frozen cod fillet in a similar way as in model 1 .

The models were also estimated for respondents who always and regularly use the information of ecolabels for make their buying decision regarding fish products (label us- 
Table 6

Estimation Results of the Panel MMNL, Model 3

\begin{tabular}{|c|c|c|c|c|c|}
\hline & Coefficient & Std. Err. & $\begin{array}{c}\text { Marginal } \\
\text { Effect Mean }\end{array}$ & ME Min & ME Max \\
\hline \multicolumn{6}{|l|}{ Mean } \\
\hline Constant & $3.285 * * *$ & 0.259 & & & \\
\hline Price & $-0.354 * * *$ & 0.01 & -0.048 & -0.083 & -0.013 \\
\hline Age & $-0.007 * *$ & 0.003 & -0.001 & -0.002 & -0.001 \\
\hline Male & $0.375 * * *$ & 0.073 & 0.048 & 0.002 & 0.090 \\
\hline $\mathrm{HH}$ size & 0.021 & 0.053 & 0.003 & 0.001 & 0.005 \\
\hline Kids & $-0.234 * *$ & 0.109 & -0.029 & -0.056 & -0.001 \\
\hline Low income & $-0.315^{*}$ & 0.171 & -0.039 & -0.076 & -0.001 \\
\hline High income & 0.751 & 0.084 & 0.009 & 0.001 & 0.018 \\
\hline Employed & -0.045 & 0.087 & -0.006 & -0.011 & -0.001 \\
\hline Single & $-0.283 * * *$ & 0.087 & -0.035 & -0.068 & -0.001 \\
\hline Fisheries worldwide & $-0.201 * * *$ & 0.05 & -0.024 & -0.059 & 0.005 \\
\hline Fisheries EU & $-0.172 * * *$ & 0.04 & -0.021 & -0.042 & -0.001 \\
\hline Heavily overfished & $-3.240 * * *$ & 0.12 & -0.280 & -0.561 & -0.001 \\
\hline Slightly overfished & $-0.832 * * *$ & 0.05 & -0.081 & -0.207 & 0.011 \\
\hline Bycatch & $-1.906^{* * *}$ & 0.10 & -0.171 & -0.422 & 0.016 \\
\hline MSC label & $0.345 * * *$ & 0.04 & 0.034 & -0.004 & 0.102 \\
\hline \multicolumn{6}{|l|}{ SD Standard Deviation } \\
\hline Fisheries worldwide & $0.513 * * *$ & 0.06 & & & \\
\hline Fisheries EU & 0.028 & 0.07 & & & \\
\hline Heavily overfished & $2.304 * * *$ & 0.10 & & & \\
\hline Slightly overfished & $0.705 * * *$ & 0.06 & & & \\
\hline Bycatch & $2.053 * * *$ & 0.07 & & & \\
\hline MSC label & $0.574 * * *$ & 0.06 & & & \\
\hline Log-likelihood & $-9,366.29$ & & & & \\
\hline Aike information criteria & $18,776.57$ & & & & \\
\hline Observations & 36,360 & & & & \\
\hline Participants & 505 & & & & \\
\hline
\end{tabular}

ers) and respondents who rarely or never use the labels (nonlabel users). The results can be found in Appendix Tables A1 to A6. For the label user, the label is a stronger information device. The information about environmental concerns function is $0.284(73 \%)$ of the ecolabel's initial marginal effect of 0.388 $(100 \%)$ for those consumers. The warm glow effect is just $0.07(18 \%)$, and the residual marginal effect is $0.034(9 \%)$ for label users. For respondents who rarely or never use an ecolabel when buying seafood (nonlabel users), the original marginal effect of the MSC label is very low at 0.052. Supplying additional information in treatment 2 only slightly affects the marginal effect of the MSC label as it increases to 0.058 . This finding is in line with the expected behavior of nonlabel users toward its warm glow function (0.030) and a residual marginal effect $(0.028(54 \%))$.

\section{Discussion and Conclusion}

This article analyzes seafood buying decisions in three independent DCEs. In total, 1,453 German fish-consuming respondents were randomly allocated to three experiments. These experiments were designed to disentangle two different motivations for purchasing an ecolabeled seafood product and to quantify their relative magnitudes. First, the ecolabel may provide information about the sustainability of the production process. Second, consumers may also receive a good feeling or warm glow (Andreoni 1989, 1990) from the green behavior of purchasing MSC-certified products. Buying a product labeled "sustainable" may create a warm glow independently of the actual properties of the production process of the fish product. Finally, there may be 
other motivations due to idiosyncratic interpretations of the MSC label.

The three DCEs are designed to disentangle these motivations. In a first experiment, participants chose based on the attributes price and presence or absence of the MSC label. In a second experiment, additional product attributes were included that provided independent information about the sustainability of the products. Hence, the MSC label becomes redundant as an information device. We thus interpret the decrease of the MSC's marginal effect by $63 \%$ between experiments 1 and 2 as the effect of the label's information about environmental concerns, which is present in treatment 1 but lost in treatment 2. Still, the presence of the MSC label has a positive effect on the choice probability in the second treatment. We attribute this effect to the remaining warm glow effect of the ecolabel and any further factors. To measure the warm glow effect, a third treatment included contradictory attribute-level combinations, such that an MSC-certified fish product could come from a fish stock classified as heavily overfished. These contradictory attribute combinations were supposed to destroy warm glow. A decrease of 24\% of the ecolabel's initial marginal effect was found between the second and third treatments. Interpreting this difference as destroyed warm glow, 63\% of the ecolabel's marginal effect in treatment 1 can be attributed to its information about environmental concerns function, $24 \%$ to its warm glow function, and a residual marginal effect of $13 \%$. Our attribution of differences in marginal effects to the information about environmental concerns and warm glow motivations rests on the assumption that the respondents find the information we provide in the DCE at least equally reliable and comprehensive as the information provided by the MSC label. The rather strong difference in marginal effects between the first two experiments supports this assumption. Attributing the reduction in marginal effects between the experiments 2 and 3 to the warm glow motivation further rests on the assumption that the contradictory information fully destroys the warm glow effect. This is not necessarily the case, as choice cards are presented to the respondents in a random order. Thus, we observe some choices of respondents before they see the first contradictory choice, and the estimate of $23 \%$ is on the conservative side. The true warm glow effect may be actually somewhat larger. The results in this article shed light on some of the controversies that surrounds the increasing importance of ecolabels for seafood. These are often criticized for not improving sustainability (Sampson et al. 2015; Roheim et al. 2018). Our results show that a major motivation for preferring an ecolabeled product is the information about environmentally friendly production. For these consumers, it is important that the labels provide reliable information. Our results also show that a substantial motivation to buy ecolabeled products is personal warm glow.

These results can justify provision of ecolabeled products even if their effect on the production practices are limited. This is highly relevant in the seafood sector, as a large and increasing number of ecolabels are provided (Alfnes, Chen, and Rickertsen 2018; Osmundsen et al. 2020), while the effect on production practices and fish stock health remains controversial (Roheim et al. 2018; Tlusty et al. 2019). Hence, the results add to the literature that argues there may well be a market for ecolabels even if they have no effect on the sustainability of the production process.

The different motivations of consumers to buy ecolabeled products is policy relevant. Our results show that consumers have a concern for sustainability. A major motivation to choose the ecolabeled seafood is that this allows the consumer to pick the sustainable product and privately contribute to a social objective. This motivation and the provision of information about the sustainability of the production deserve public support. A warm glow effect, by contrast, is a purely private good. By definition, it does not depend on the actual contribution to a social goal. To the extent that ecolabels provide a warm glow motivation, no public intervention in the market is justified. A large and increasing number of different ecolabels has become available on the market, and it becomes increasingly difficult for consumers to make use of the information function of ecolabels (Grunert, Hieke, and Wills 2014; Roheim et al. 2018). The 
warm glow effect may be the only motivation remaining for consumers to buy ecolabeled products. Whereas this effect renders ecolabels valuable for consumers to some extent, our results also show that the main benefit of an ecolabel is the provision of information about the sustainability of the production process. If the market fails to provide this function, public intervention may be required to ensure that labels exist that provide this service.

\section{Acknowledgments}

The authors acknowledge the support of the German Centre for Integrative Biodiversity Research (iDiv) Halle-Jena-Leipzig, funded by the German Research Foundation (FZT 118), and the financial support of the Norwegian Research Council (CT 281040 and CT 295114). The authors also acknowledge support from the iDiv Open Science Publication Fund.

\section{References}

Ahluwalia, R., R. E. Burnkrant, and H. R. Unnava. 2000. "Consumer Response to Negative Publicity: The Moderating Role of Commitment." Journal of Marketing Research 37 (2): 203-14. https://doi.org/10.1509/jmkr.37.2.203.18734.

Alfnes, F., X. Chen, and K. Rickertsen. 2018. "Labeling Farmed Seafood: A Review." Aquaculture Economics \& Management 22 (1): 1-26. https://doi.org/10.1080/13657305.2017.13563 98.

Andreoni, J. 1989. "Giving with Impure Altruism: Applications to Charity and Ricardian Equivalence." Journal of Political Economy 97 (6): 1447-58. https://doi.org/10.1086/261662.

1990. "Impure Altruism and Donations to Public Goods: A Theory of Warm-Glow Giving." Economic Journal 100 (401): 464. https:// doi.org/10.2307/2234133.

Asche, F., and J. Bronnmann. 2017. "Price Premiums for Ecolabelled Seafood: MSC Certification in Germany." Australian Journal of Agricultural and Resource Economics 61 (4): 576-89. https://doi.org/10.1111/1467-8489.12217.

Asche, F., T. A. Larsen, M. D. Smith, G. Sogn-Grundvåg, and J. A. Young. 2015. "Pricing of Eco-labels with Retailer Hetero- geneity." Food Policy 53: 82-93. https://doi. org/10.1016/j.foodpol.2015.04.004.

Blackman, A., L. Goff, and M. Rivera Planter. 2018. "Does Eco-certification Stem Tropical Deforestation? Forest Stewardship Council Certification in Mexico." Journal of Environmental Economics and Management 89: 30633. https://doi.org/10.1016/j.jeem.2018.04.005.

Brécard, D., B. Hlaimi, S. Lucas, Y. Perraudeau, and F. Salladarré. 2009. "Determinants of Demand for Green Products: An Application to Eco-Label Demand for Fish in Europe." Ecological Economics 69 (1): 115-25. https://doi. org/10.1016/j.ecolecon.2009.07.017.

Bronnmann, J., and F. Asche. 2016. "The Value of Product Attributes, Brands and Private Labels: An Analysis of Frozen Seafood in Germany." Journal of Agricultural Economics 67 (1): 23144. https://doi.org/10.1111/1477-9552.12138.

. 2017. "Sustainable Seafood from Aquaculture and Wild Fisheries: Insights from a Discrete Choice Experiment in Germany." Ecological Economics 142: 113-19. https://doi. org/10.1016/j.ecolecon.2017.06.005.

Bronnmann, J., and J. Hoffmann. 2018. "Consumer Preferences for Farmed and Ecolabeled Turbot: A North German Perspective." Aquaculture Economics \& Management 22 (3): 342-61. https://doi.org/10.1080/13657305.201 8.1398788 .

Carlsson, F., and P. Martinsson. 2008. "How Much Is Too Much?" Environmental and Resource Economics 40 (2): 165-76. https://doi. org/10.1007/s10640-007-9146-z.

Christian, C., D. Ainley, M. Bailey, P. Dayton, J. Hocevar, M. LeVine, J. Nikoloyuk, et al. 2013. "A Review of Formal Objections to Marine Stewardship Council Fisheries Certifications." Biological Conservation 161: 10-17. https:// doi.org/10.1016/j.biocon.2013.01.002.

Crumpler, H., and P. J. Grossman. 2008. "An Experimental Test of Warm Glow Giving." Journal of Public Economics 92 (5-6): 1011-21. https://doi.org/10.1016/j.jpubeco.2007.12.014.

Destatis. 2008. Einkommens- und Verbrauchsstichprobe 2008, Grundfile 4,Nahrungsmittel, Getränke, Tabakwaren. Wiesbaden, Germany: Statistisches Bundesamt.

Dunning, D. 2007. "Self-Image Motives and Consumer Behavior: How Sacrosanct Self-Beliefs Sway Preferences in the Marketplace." Journal of Consumer Psychology 17 (4): 237-49. https:// doi.org/10.1016/S1057-7408(07)70033-5. 
Ecolabel Index. 2018. http://www.ecolabelindex. com/ (accessed 27 May 2018).

Fonner, R., and G. Sylvia. 2015. "Willingness to Pay for Multiple Seafood Labels in a Niche Market." Marine Resource Economics 30 (1): 51-70. https://doi.org/10.1086/679466.

Grebitus, C., H. H. Jensen, and J. Roosen. 2013. "US and German Consumer Preferences for Ground Beef Packaged under a Modified Atmosphere: Different Regulations, Different Behaviour?" Food Policy 40: 109-18.

Grolleau, G., L. Ibanez, and N. Mzoughi. 2009. "Too Much of a Good Thing? Why Altruism Can Harm the Environment." Ecological Economics 68 (7): 2145-49. https://doi. org/10.1016/j.ecolecon.2009.02.020.

Grunert, K. G., S. Hieke, and J. Wills. 2014. "Sustainability Labels on Food Products: Consumer Motivation, Understanding and Use." Food Policy 44: 177-89. https://doi.org/10.1016/j.food pol.2013.12.001.

Gutiérrez, N. L., S. R. Valencia, T. A. Branch, D. J. Agnew, J. K. Baum, P. L. Bianchi, J. Cornejo-Donoso, et al. 2012. "Eco-label Conveys Reliable Information on Fish Stock Health to Seafood Consumers." PLoS One 7 (8): e43765. https://doi.org/10.1371/journal.pone.0043765.

Hartmann, P., M. Eisend, V. Apaolaza, and C. D'Souza. 2017. "Warm Glow vs. Altruistic Values: How Important Is Intrinsic Emotional Reward in Proenvironmental Behavior?" Journal of Environmental Psychology 52: 43-55. https://doi.org/10.1016/j.jenvp.2017.05.006.

Hensher, D. A., P. R. Stopher, and J. J. Louviere. 2001. "An Exploratory Analysis of the Effect of Numbers of Choice Sets in Designed Choice Experiments: An Airline Choice Application." Journal of Air Transport Management 7 (6): 373-79. https://doi.org/10.1016/S09696997(01)00031-X.

Hole, A. R. 2007. "Estimating Mixed Logit Models Using Maximum Simulated Likelihood." Stata Journal 7 (3): 388-401.

Jaffry, S., H. Pickering, Y. Ghulam, D.Whitmarsh, and P. Wattage. 2004. "Consumer Choices for Quality and Sustainability Labelled Seafood Products in the UK." Food Policy 29 (3): 215-28. https://doi.org/10.1016/j.foodpol.2004.04.001.

Johnston, R. J., and C. A. Roheim. 2006. "A Battle of Taste and Environmental Convictions for Ecolabeled Seafood: A Contingent Ranking Experiment." Journal of Agricultural and Resource Economics 31 (2): 283-300.
Johnston, R. J., C. R. Wessells, H. Donath, and F. Asche. 2001. "Measuring Consumer Preferences for Ecolabeled Seafood: An International Comparison." Journal of Agricultural and Resource Economics 26 (1): 20-39.

Leire, C., and A. Thidell. 2005. "Product-Related Environmental Information to Guide Consumer Purchases: A Review and Analysis of Research on Perceptions, Understanding and Use among Nordic Consumers." Journal of Cleaner Production 13 (10-11): 1061-70. https://doi. org/10.1016/j.jclepro.2004.12.004.

Lidl. 2018. Positionsapier für den nachhaltigen Einkauf von Fisch, Schalentieren und deren Erzeugnissen. Available at https://www.lidl. de/de/asset/other/Positionspapier-fur-den-nach haltigeren-Einkauf-von-Fisch-Schalentierennd-deren-Erzeugnisse.pdf.

Louviere, J. J. 2004. "Random Utility TheoryBased Stated Preference Elicitation Methods: Applications in Health Economics with Special Reference to Combining Sources of Preference Data." CenSoC Working Paper No. 04-001. Available at http://citeseerx.ist.psu.edu/view doc/download?doi=10.1.1.137.3803\&rep=rep $1 \&$ type $=$ pdf.

Martin, S. M., T. A. Cambridge, C. Grieve, F. M. Nimmo, and D. J. Agnew. 2012. "An Evaluation of Environmental Changes within Fisheries Involved in the Marine Stewardship Council Certification Scheme." Reviews in Fisheries Science 20 (2): 61-69. https://doi.org/10.1080/ 10641262.2011.654287.

Marx, A., M. Maertens, and J. F. M. Swinnen. 2012. Private Standards and Global Governance: Economic, Legal and Political Perspectives. Cheltenham, UK: Edward Elgar.

Mason, C. F. 2006. "An Economic Model of Ecolabeling." Environmental Modeling and Assessment 11 (2): 131-43. https://doi.org/10.1007/ s10666-005-9035-1.

McFadden, D. 1974. "Conditional Logit Analysis of Qualitative Choice Behavior." In Frontiers in Econometrics, edited by P. Zarembka, 105-42. New York: Academic Press.

Onozaka, Y., and D. T. McFadden. 2011. "Does Local Labeling Complement or Compete with Other Sustainable Labels? A Conjoint Analysis of Direct and Joint Values for Fresh Produce Claim." Ecological Economics 93 (3): 693706. https://doi.org/10.1093/ajae/aar005.

Opitz, S., J. Hoffmann, M. Quaas, N. Matz-Lück, C. Binohlan, and R. Froese. 2016. "Assessment of MSC-certified Fish Stocks in the Northeast 
Atlantic." Marine Policy 71: 10-14. https://doi. org/10.1016/j.marpol.2016.05.003.

Osmundsen, T. C., V. S. Amundsen, K. A. Alexander, F. Asche, J. Bailey, B. Finstad, M. S. Olsen, K. Hernández, and H. Salgado. 2020. "The Operationalisation of Sustainability: Sustainable Aquaculture Production as Defined by Certification Schemes." Global Environmental Change 60. https://doi.org/10.1016/j.gloenv cha.2019.102025.

Roheim, C. A., S. R. Bush, F. Asche, J. N. Sanchirico, and H. Uchida. 2018. "Evolution and $\mathrm{Fu}-$ ture of the Sustainable Seafood Market." $\mathrm{Na}$ ture Sustainability 1 (8): 392-98. https://doi. org/10.1038/s41893-018-0115-z.

Roheim, C. A., and D. Zhang. 2018. "Sustainability Certification and Product Substitutability: Evidence from the Seafood Market." Food Policy 79: 92-100. https://doi.org/10.1016/j.food pol.2018.06.002.

Salladarré, F., P. Guillotreau, Y. Perraudeau, and M.-C. Monfort. 2010. "The Demand for Seafood Eco-labels in France." Journal of Agricultural \& Food Industrial Organization 8 (1). https://doi.org/10.2202/1542-0485.1308.

Sammer, K., and R. Wüstenhagen. 2006. "The Influence of Eco-labelling on Consumer Behaviour: Results of a Discrete Choice Analysis for Washing Machines." Business Strategy and the Environment 15 (3): 185-99. https://doi. org/10.1002/bse.522.

Sampson, G. S., J. N. Sanchirico, C. A. Roheim, S. R. Bush, J. E. Taylor, E. H. J. L. Anderson, N. C. Ban, et al. 2015. "Secure Sustainable Seafood from Developing Countries." Science 348 (6234): 504-506. https://doi.org/10.1126/ science.aaa4639.

Sexton, S. E., and A. L. Sexton. 2014. "Conspicuous Conservation: The Prius Halo and Willingness to Pay for Environmental Bona Fides." Journal of Environmental Economics and Management 67 (3): 303-17. https://doi. org/10.1016/j.jeem.2013.11.004.

Sogn-Grundvåg, G., F. Asche, D. Zhang, and J. A. Young. 2019. "Eco-labels and Product Longevity: The Case of Whitefish in UK Grocery Retailing." Food Policy 88. https://doi. org/10.1016/j.foodpol.2019.101750.
Sogn-Grundvåg, G., T. A. Larsen, and J. A. Young. 2013. "The Value of Line-Caught and Other Attributes: An Exploration of Price Premiums for Chilled Fish in UK Supermarkets." Marine Policy 38: 41-44. https://doi.org/10.1016/j.mar pol.2012.05.017.

Thøgersen, J., P. Haugaard, and A. Olesen. 2010. "Consumer Responses to Ecolabels." European Journal of Marketing 44 (11/12): 1787-810. https://doi.org/10.1108/03090561011079882.

Tlusty, M. F., P. Tyedmers, M. Bailey, F. Ziegler, P. J. G. Henriksson, C. Béné, S. Bush, et al. 2019. "Reframing the Sustainable Seafood Narrative." Global Environmental Change 59. https:// doi.org/10.1016/j.gloenvcha.2019.101991.

Uchida, H., Y. Onozaka, T. Morita, and S. Managi. 2014a. "Demand for Ecolabeled Seafood in the Japanese Market: A Conjoint Analysis of the Impact of Information and Interaction with Other Labels." Food Policy 44: 68-76. https:// doi.org/10.1016/j.foodpol.2013.10.002.

Uchida, H., C. A. Roheim, H. Wakamatsu, and C. M. Anderson. 2014b. "Do Japanese Consumers Care about Sustainable Fisheries?: Evidence from an Auction of Ecolabelled Seafood." Australian Journal of Agricultural and Resource Economics 58 (2): 263-80. https://doi. org/10.1111/1467-8489.12036.

van der Linden, S. 2018. "Warm Glow Is Associated with Low- But Not High-Cost Sustainable Behaviour." Nature Sustainability 1 (1): 28-30. https://doi.org/10.1038/s41893-017-0001-0.

Wessells, C. R., R. J. Johnston, and H. Donath. 1999. "Assessing Consumer Preferences for Ecolabeled Seafood: The Influence of Species, Certifier, and Household Attributes." American Journal of Agricultural Economics 81 (5): 1084-89.

Wittink, D. R., L. Krishnamurthi, and J. B. Nutter. 1982. "Comparing Derived Importance Weights across Attributes." Journal of Consumer Research 8 (4): 471-74. https://doi. org/10.1086/208890.

Zhou, G., W. Hu, and W. Huang. 2016. "Are Consumers Willing to Pay More for Sustainable Products? A Study of Eco-labeled Tuna Steak." Sustainability 8 (5): 494. https://doi. org/10.3390/su8050494. 